\title{
Peningkatan Hasil Belajar Pai Dengan Pendekatan Kontekstual Pada Siswa Kelas IV SD Negeri Teh Semester Ganjil Tahun Pelajaran 2019/2020
}

\author{
Sulaiman M.Amin \\ SD Negeri Teh \\ sulaiman_amin62@gmail.com
}

\begin{abstract}
Penelitian ini bertujuan untuk mengetahu apakah ada peningkatan hasil belajar PAI dengan Pendekatan Kontekstual pada Siswa Kelas IV SD Negeri Teh Semester Ganjil Tahun Pelajaran 2019/2020. Subyek Dalam penelitian ini adalah siswa kelas IV SD Negeri Teh Pelajaran 2019/2020 dengan jumlah 22 siswa. Rancangan penelitian ini menggunakan rancangan penelitian tindakan kelas dengan dua siklus. Setiap siklus meliputi tahap perencanaan, pelaksanaan, pengamatan, dan refleksi. Hasil penelitian ini disimpulkan bahwa Pembelajaran dengan pendekatan kontekstual memiliki dampak positif dalam meningkatkan hasil belajar siswa yang ditandai dengan peningkatan ketuntasan belajar siswa dalam setiap siklus, yaitu siklus I 40,91\% dengan nilai rata-rata 50, siklus II 86,36\% dengan nilai rata-rata 80. Penerapan pendekatan kontekstual mempunyai pengaruh positif, yaitu dapat meningkatkan aktivitas belajar siswa yang ditunjukan dengan hasil observasi per siklus menunjukkan peningkatan. Pada siklus I keaktifan siswa tergolong cukup aktif dengan persentase 65\%. Pada siklus II mengalami peningkatan yang tergolong sangat aktif dengan persentase $90 \%$.
\end{abstract}

Keywords: Hasil Belajar, Pendekatan Kontekstual

\section{PENDAHULUAN}

Guru merupakan faktor penentu bagi keberhasilan pembelajaran untuk meningkatkan mutu pendidikan, sebab guru berhadapan langsung dengan siswa di sekolah, oleh karena itu, peran guru sangat berpengaruh strategis dalam meningkatkan pembelajaran di kelas (Azmin dan Nasir, 2019).

Dalam konteks ini, guru perlu mengikuti perubahan-perubahan paradigma yang sedang terjadi. Sebagai contoh pada saat pembelajaran PAI di dalam kelas tampak monoton, siswa kurang diberi ruang dan waktu yang memadai untuk mempraktikkan dan menggunakan pelajaran PAI yang mereka pelajari dalam berwacana, mereka pada umumnya hanya menjawab dan mengerjakan tugas-tugas secara sepotong, sangat jarang siswa dilatih untuk mengutarakan pikiran dan penalaran mereka, baik individu maupun kelompok sebagai praktek wacana dalam tindakan sosial, pengelolaan pembelajaranpun tampak statis. Akibatnya, banyak peserta didik yang menggagap enteng pelajaran Pendidikan Agama Islam, mereka kurang serius mengikuti pelajaran. Bahkan, sering dijumpai pembelajar yang bersifat antipati
(Hoy dkk, 2018).

Kurangnya informasi yang diketahui siswa dalam memecahkan suatu permasalahan akan berakibat salah atau kelirunya jawaban yang diharapkan. Dalam hal ini siswa hanya berpusat kepada guru sebagai pusat informasi. Dengan kata lain dari penjelasan di atas bahwa proses pembelajaran di sekolah hanya terjadi satu arah. Keadaan kelas kurang kondusif, dimana siswa hanya menunggu jawaban, sehingga mengakibatkan siswa menjadi kurang aktif dalam belajar. Dalam hal mencari tahu atau menemukan informasi yang dibutuhkannya hanya berpedoman dari guru semata. Sedangkan pendidikan tujuannya adalah menjadikan manusia seutuhnya. Pendidikan yang hakiki bukan hanya berasal dari satu arah, melainkan berkebutuhan dan melengkapi satu dengan yang lainnya. Pendidikan yang aktif mengajarkan siswa untuk mencari dan menemukembangkan apa yang menjadi permasalahan dan bagaimana solusinya, dan guru bertugas sebagai fasilitator serta pembimbing (Trianto, 2010). Dengan demikian pendidikan sangat penting bagi kelangsungan hidup di dunia dan di akhirat. Pendidikan jugalah yang akan membuat 
pengetahuan manusia berkembang. Sedangkan pendidikan diartikan sebagai suatu kegiatan yang bertujuan untuk membentuk manusia agamis dengan menanamkan aqidah keimanan, amaliah dan Beriman kepada Allah dan Rasulnya atau akhlak yang terpuji untuk menjadi manusia yang taqwa kepada Allah SWT.

Berdasarkan hasil pengamatan dan pengalaman selama ini, siswa kurang aktif dalam kegiatan belajar-mengajar, anak cenderung tidak begitu tertarik dengan pelajaran PAI, karena selama ini pelajaran PAI dianggap sebagai pelajaran yang hanya mementingkan hafalan semata, kurang menekankan aspek penalaran sehingga menyebabkan rendahnya hasil belajar PAI siswa di sekolah.

Banyak faktor yang menyebabkan hasil belajar PAI siswa rendah, yaitu faktor internal dan eksternal siswa. Faktor internal antara lain: motivasi belajar, intelegensi, kebiasaan dan rasa percaya diri. Sedangkan faktor eksternal adalah faktor yang terdapat di luar siswa, seperti guru sebagai pembina kegiatan belajar, strategi pembelajaran, sarana dan prasarana, kurikulum dan lingkungan.

Dari masalah yang dikemukakan di atas, perlu dicari strategi baru dalam pembelajaran yang melibatkan siswa secara aktif. Pembelajaran yang mengutamakan penguasaan kompetensi harus berpusat pada siswa (focus on learners), memberikan pembelajaran dan pengalaman belajar yang relevan dan kontekstual dalam kehidupan nyata (provide relevant and contextualized subject matter) dan mengembangkan mental yang kaya dan kuat pada siswa. Disinilah guru dituntut untuk merancang kegiatan pembelajaran yang mampu mengembangkan kompetensi, baik dalam ranah kognitif, ranah afektif maupun psikomotorik siswa. Strategi pembelajaran yang berpusat pada siswa dan penciptaan suasana yang menyenangkan sangat diperlukan untuk nmeningkatkan hasil belajar siswa (Anni, 2009).

Dalam hal ini memilih model pembelajaran aktif menekankan kepada aktivitas siswa secara optimal untuk memperoleh hasil belajar perpaduan antara aspek kognitif, afektif, dan psikomotorik secara seimbang. Pembelajaran harus dibuat dalam suatu kondisi yang menyenangkan sehingga siswa akan terus termotivasi dari awal sampai akhir kegiatan belajar mengajar. Dalam hal ini pembelajaran Contextual merupakan salah satu alternatif yang dapat digunakan guru di sekolah untuk meningkatkan kualitas pembelajaran. Proses kontekstual, pada dasarnya merupakan proses menyadari sesuatu, memahami permasalahan, proses adaptasi dan organisasi, proses asimilasi dan merefleksikan serta proses membuat komposisi dan membuka ulang secara terbuka dan dinamis.

\section{METODE \\ Jenis Penelitian}

Penelitian ini merupakan penelitian tindakan Kelas, karena penelitian dilakukan untuk memecahkan masalah pembelajaran di kelas. Penelitian ini juga termasuk penelitian deskriptif, sebab menggambarkan bagaimana suatu teknik pembelajaran diterapkan dan bagaimana hasil yang diinginkan dapat dicapai.

\section{Waktu dan Tempat Penelitian}

Penelitian ini dilaksanakan di Sekolah SDN Teh Kabupaten Bima, mulai bulan April sampai Agustus Tahun 2019

\section{Subyek Penelitian}

Subyek dalam penelitian ini adalah siswa kelas IV yang berjumlah 22 orang siswa.

\section{Prosedur Penelitian}

Penelitian ini berbentuk Penelitian Tindakan Sekolah (School Action Research), yaitu sebuah penelitian yang merupakan kerjasama antara peneliti dan guru, dalam meningkatkan kemampuan guru agar menjadi lebih baik dalam menyusun proses pembelajaran.

\section{Perencanaan}

Perencanaan yaitu kegiatan menetapkan tindakan yang akan dilakukan dalam proses pembelajaran. Perencanaan merupakan persiapan yang akan dilakukan sehubungan dengan pendekatan 
kontekstualuntuk menyelesaikan masalah. Rencana kegiatan yang akan dilakukan pada tahap ini adalah (a) menyiapkan materi dan menyusun rencana pembelajaran, (b) menyediakan media dan alat yang akan digunakan dalam proses pembelajaran, (c) membuat dan menyiapkan soal yang akan digunakan untuk mengukur hasil belajar siswa

2. Pelaksanaan Tindakan

Pada tahap ini, pelaksanaan tindakan merupakan suatu kegiatan yang dilaksanakannya tahapan pembelajaran yang telah direncanakan. Dalam hal ini melaksanakan pembelajaran dengan menerapakan pendekatan kontekstual sesuai dengan Rencana Pelaksanaan Pembejaran (RPP) yang telah disiapkan.

3. Observasi

Pengamatan adalah suatu kegiatan mengamati jalannya tindakan dengan menggunakan lembar observasi aktivitas belajar siswa dan guru untuk memantau sejauh mana efek tindakan pembelajaran dengan menggunakan pendekatan kontekstual pada tiap siklus.

4. Refleksi

Refleksi adalah kegiatan untuk mengemukakan kembali apa yang sudah terjadi. Kegiatan mengulas secara kritis tentang perubahan yang terjadi pada siswa, guru, dan suasana kelas. Berdasarkan hasil reflsksi ini, peneliti dapat melakukan revisi terhadap rencana kegiatan selanjutnya atau terhadap rencana siklus II. Pada tahap ini, peneliti menganalisis tes siklus I. Dari hasil tersebut nantinya akan dibandingkan dengan hasil tes siklus II. Masalah-masalah yang timbul pada siklus I akan dicarikan alternatif pemecahannya pada siklus II. Sedangkan kelebihannya akan dipertahankan dan diringkatkan lagi.

\section{Instrumen Penelitian}

Instrument yang digunakan dalam penelitian ini terdiri dari:

1. Tes Evaluasi

2. Lembar Kerja Siswa (LKS)

3. Lembar Observasi

\section{Teknik Pengumpulan Data}

1. Tes. Tes dalam penelitian ini diberikan pada setiap akhir siklus atau setelah setelah dibelajarkan dengan pendekatan kontekstual. Tes dilakukan secara tertulis, untuk mendapatkan hasil belajar siswa.

2. Observasi. Lembar observasi digunakan untuk mengamati aktivitas belajar siswa.

\section{Teknik Analisis Data}

Analisis data adalah menganalisis tingkat keberhasilan atau persentase keberhasilan setelah proses pembelajaran setiap siklus dilakukan dengan cara memberi evaluasi berupa soal tes tertulis pada setiap akhir siklus, dengan mengacu pada Kriteria ketuntasan Klasikal 85\%.

\section{HASIL DAN PEMBAHASAN}

Sebelum dilakukan penelitian tindakan kelas ini pembelajaran masih menggunakan metode pembelajaran yang kurang inovatif, yaitu pembelajaran masih berpusat pada guru sehingga aktivitas belajar siswa masih kurang optimal. Selain itu guru juga masih menggunakan media buku paket dalam menyampaikan materi sehingga hasil belajar siswa kurang optimal. Hasil belajar siswa yang masih rendah dan belum mencapai kriteria ketuntasan minimal (KKM), yaitu sebesar $34,78 \%$.

\section{A. Hasil}

\section{Siklus I}

Pelaksanaan Penelitian Tindakan Kelas ini dilakukan dalam 2 (dua) siklus. Setiap siklus terdiri dari dua pertemuan. Setiap siklus berisi materi dengan menggunakan pendekatan kontekstual dan diakhiri dengan pemberian tes terkait hasil pembelajaran yang telah dilakukan. Pelaksanaan siklus I dilaksanakan dengan dua tahap, yaitu

\section{Perencanaan}

Pada tahap ini, peneliti mempersiapkan rencana pengajaran yang mengacu pada tujuan pembelajaran. Di samping rencana pembelajaran, perlu dipersiapkan juga alatalat yang menunjang pembelajaran seperti papan tulis, LCD, buku pelajaran, dan lain sebagainya. Peneliti juga perlu melakukan 
wawancara kepada siswa kelas IV SD Negeri Teh untuk mengetahui keadaan siswa sebelum melakukan tindakan. Perencanaan tindakan adalah tindak lanjut dari observasi awal serta bagaimana cara memecahkan persoalan pembelajaran di kelas IV SD Negeri Teh tersebut. Hal ini kemudian diterapkan dalam rencana penelitian tindakan kelas dengan membentuk sebuah pengajaran dengan penerapan Pendekatan kontekstual. Rencana Pelaksanaan Pembelajaran (RPP) disusun dengan memperhatikan: kompetensi inti,kompetensi dasar, indikator, tujuan pembelajaran, materi pokok, metode pembelajaran, langkah-langkah pembelajaran, sumber belajar/alat/bahan, media pembelajaran, dan penilaian

\section{Pelaksanaan Tindakan}

Pada tahap ini merupakan pelaksanaan dari perencanaan yang telah dipersiapkan peneliti. Proses tindakan dalam penelitian ini meliputi kegiatan awal, kegiatan inti, dan kegiatan akhir pada saat proses pembelajaran berlangsung. Sebelum melakukan tindakan, peneliti mengkondisikan kelas. Hal ini untuk mempermudah peneliti dalam penilaian pembelajaran pada siswa kelas IV yang jumlah siswanya hanya 22 siswa.

Dalam kegiatan awal, peneliti mengkondisikan siswa agar siap melaksanakan proses pembelajaran. Kegiatan awal ini berupa kegiatan peneliti menyapa siswa Hal ini menunjukkan bahwa peneliti mensintesis siswa untuk aktif dan respon terhadap pembelajaran. Selanjutnya siswa bertanya kepada peneliti, hal ini menunjukkan bahwa siswa menanggapi dan aktif sejak awal dalam proses pembelajaran. Peneliti juga mengemukakan manfaat dan tujuan pembelajaran agar siswa tertarik dengan materi yang akan diajarkan dan memiliki motivasi dalam pembelajaran. Kegiatan selanjutnya peneliti menyampaikan materi Beriman kepada Allah dan Rasul-Nya. Kemudian dilanjutkan dengan memasangkan kartu atau metode yang digunakan peneliti yakni Pendekatan kontekstual dimana dalam permainan ini memanfaatkan kartu-kartu yang berbentuk bintang dan persegi panjang yang ditempatkan di atas meja agar siswa dapat menemukan jodoh dari kartu yang dipegangnya, tujuan permainan ini agar lebih bermakna dan menarik siswa belajar pada materi tersebut.

Pada kegiatan akhir, peneliti memberikan tes kepada siswa melalui gambar buta atau diagram kosong, kemudian peneliti bersama siswa melakukan refleksi terhadap pembelajaran yang telah berlangsung dan siswa diminta mempelajari kembali materi yang telah diajarkan. Peneliti juga memberikan kesempatan bagi siswa yang ingin bertanya. Kemudian melaksanakan post test dan terakhir peneliti memberikan motivasi kepada seluruh siswa agar tetap bersemangat belajar dan berlatih materi yang telah disampaikan.

\section{Pengamatan}

Hasil pengamatan siklus I dicatat dalam lembar observasi yang telah dipersiapkan. Pengamatan siklus I diperoleh $65 \%$ siswa cukup aktif dalam pembelajaran dengan menggunakan pendekatan kontekstual.

\section{Refleksi}

Berdasarkan hasil pengamatan pada siklus I baik guru maupun siswa masih kurang maksimal dalam proses pembelajaran. Adapun yang menjadi kendalanya sebagai berikut: Hasil observasi aktivitas belajar siswa mencapai $65 \%$. Hal ini menunjukkan siswa masih kurang maksimal dalam pembelajaran. Siswa masih kurang aktif dalam proses pembelajaran

Hasil evaluasi pembelajaran pembelajaran pada siklus I dengan pendekatan kontekstual mencapai 40,91\%. Hasil tersebut menunjukkan bahwa pada siklus pertama secara klasikal siswa belum tuntas belajar lebih kecil dari persentase ketuntasan yang dikehendaki yaitu sebesar $75 \%$.

\section{Hasil Siklus II}

Dari hasil siklus I yang belum mencapai ketuntasan Klasikal, maka guna memaksimalkan hasil yang diingin dicapai maka dilakukan siklus lanjutan. Siklus lanjutan ini juga terdiri dari tindakan perencanaan, pelaksanaan tindakan, observasi dan refleksi. 


\section{Perencanaan}

Perencanaan yang dilakukan pada siklus II merupakan perbaikan dari perencanaan siklus I. Berdasarkan uraian refleksi siklus I di atas, perencanaan pada siklus II ini merupakan upaya memperbaiki kekurangan-kekurangan yang ditemukan setelah dilakukan refleksi siklus I. Perbaikanperbaikan yang dilakukan sebagai bentuk perencanaan pada siklus II ini meliputi:

1) Memperbaiki skenario pembelajaran di kelas.

2) Mempersiapkan permainan dengan bentuk kartu yang lebih menarik untuk siswa.

3) Memperbaiki pengawasan dan pengamatan yang lebih agar siswa lebih tertib dan teratur.

4) Memotivasi siswa agar lebih bersemangat dalam mengikuti kegiatan pembelajaran menggunakan pendekatan kontekstual

\section{Pelaksanaan}

Pelaksanaan kegiatan belajar mengajar untuk siklus II dilaksanakan di kelas IV dengan jumlah siswa 22 siswa. Dalam hal ini peneliti bertindak sebagai guru. Adapun proses belajar mengajar mengacu pada rencana pelajaran dengan memperhatikan revisi pada siklus I, sehingga kesalahan atau kekurangan pada siklus I tidak terulang lagi pada siklus II. Pengamatan (observasi) dilaksanakan bersamaan dengan pelaksanaan belajar mengajar. Pada akhir proses belajar mengajar siswa diberi tes formatif II dengan tujuan untuk mengetahui tingkat keberhasilan siswa selama proses belajar mengajar yang telah dilakukan. Instrument yang digunakan adalah tes formatif II.

\section{Pengamatan}

Hasil pengamatan siklus I dicatat dalam lemabar observasi yang telah dipersiapkan. Pengamatan siklus I diperoleh hasil $90 \%$ siswa aktif dalam pembelajaran dengan pendekatan kontekstual.

\section{Refleksi}

Berdasarkan hasil pengamatan pada siklus II baik guru maupun siswa sudah mengalami peningkatan dalam proses pembelajaran. Adapun hasil persentasenya sebagai berikut: Hasil observasi aktivitas belajar siswa mencapai 90\%. Hal ini menunjukkan siswa sudah mulai aktif dan maksimal dalam pembelajaran. Siswa sangat antusias dalam proses pembelajaran. Siswa semakin baik dalam bertanya, dan aktif dalam berdiskusi. Hasil evaluasi pembelajaran pembelajaran pada siklus II dengan pendekatan kontekstualmengalami peningkatan dengan persentase ketuntasan kelasikal mencapai mencapai $86,36 \%$ dari 22 siswa 19 diantaranya mendapatkan skor hasil belajar diatas 75 . Hasil tersebut menunjukkan bahwa pada siklus II ini secara klasikal siswa sudah tuntas dari persentase ketuntasan yang dikehendaki yaitu sebesar $85 \%$. Adanya peningkatan hasil belajar siswa ini karena siswa sudah mulai akrab dan menemuan keasyikan dengan pendekatan kontekstual. Disamping itu kemampuan guru dalam mengelola proses belajar mengajar dalam metode ini juga semakin meningkat sehingga proses belajar-mengajar semakin efektif.

\section{B. PEMBAHASAN}

Berdasarkan tes hasil belajar yang dilakukan tiap pembelajaran persiklusnya diketahui bahwa siswa semakin aktif pada pertemuan berikutnya, meskipun hasilnya belum sesuai harapan. Hal ini ditandai dengan semakin meningkatnya jumlah ketuntasan. Pada siklus I persentase ketuntasan 40,91\% dengan nilai rata-rata 50. Pada siklus II persentase ketuntasan $86,36 \%$ dengan nilai rata-rata 80 . Pada tahap ini siswa sudah aktif dalam proses belajar mengajar dan siswa sudah memahami materi yang diajarkan pada materi sebelumnya.

Berdasarkan hasil observasi aktivitas belajar siswa menunjukkan peningkatan. Pada siklus I keaktifan siswa tergolong cukup aktif dengan persentase $65 \%$ karena siswa masih terpengaruh terhadap situasi di luar kelas dan tidak berusaha menjawab pertanyaan yang diberikan oleh guru. Sedangkan pada siklus II mengalami peningkatan yang tergolong sangat aktif dengan persentase $90 \%$ dikarenakan siswa telah memperbaiki kesalahan pada siklus I diantaranya tidak terpengaruh terhadap situasi di luar kelas dan berusaha menjawab pertanyaan yang 
diberikan oleh guru serta bertanya apabila mengalami kesulitan.

Peningkatan hasil dan aktivitas belajar merupakan tolak ukur untuk mengetahui tingkat keberhasilan siswa dalam proses belajar mengajar (Ruslan, 2020). Proses belajar mengajar dikatakan baik, bila proses tersebut dapat membangkitkan kegiatan belajar yang efektif. Jika dilihat dari hasil belajar yang diperoleh siswa persiklus mengalami peningkatan. Peningkatan hasil belajar dikarenakan adanya peningkatan aktivitas guru dan siswa pada siklus I dan II, artinya proses pembelajaran dengan pendekatan kontekstual mengalami perbaikan. Menurut (Nurasiah dkk, 2015). Salah satu peningkatan hasil belajar siswa disebabkan terjadinya Pendekatan Kontekstual. Hal ini dikarenakan pembentukan Pendekatan Kontekstual yang heterogen berdasarkan perbedaan kemampuan akademis dan jenis kelamin, pembentukan kelompok heterogen memberikan dampak positif karena dalam pembelajarannya terjadi beberapa interaksi antar siswa yang dapat menguntungkan baik untuk guru maupun untuk siswa (Bafadal, 2020)

Berdasarkan hasil keseluruhan dari pra siklus, siklus I dan siklus II, pelaksanaan pembelajaran pada materi Beriman kepada Allah dan Rasulnya yang menerapkan Pendekatan kontekstual menunjukkan adanya peningkatan pemahaman konsep, keaktifan siswa, dan ketuntasan klasikal, sehingga pada siklus II semua indikator yang ditentukan sudah dipenuhi, bahkan sampai memenuhi nilai maksimal

\section{KESIMPULAN}

Berdasarkan hasil pembahasan diatas dapat disimpulkan bahwa: ada ada peningkatan hasil belajar PAI dengan Pendekatan Kontekstual pada Siswa Kelas IV SD Negeri Teh Semester Ganjil Tahun Pelajaran 2019/2020, dengan persentase ketuntasan 40,91\% dengan nilai rata-rata 50 pada siklus I dan meningkata menjadi $86,36 \%$ dengan nilai rata-rata 80 pada siklus II.

\section{DAFTAR PUSTAKA}

Anni. 2009. Psikologi Belajar. Semarang. UPT MKK UNNES

Azmin, N., \& Nasir, M. (2019). Penerapan Model Pembelajaran 5E Untuk Meningkatkan Keterampilan Proses Sains Dan Sikap Ilmiah Siswa Kelas VIII SMP NEGRI 6 KOTA Bima. ORYZA Jurnal Pendidikan Biologi, 8(2), 40-46.

Bafadal, I. 2002. Akselerasi Peningkatan Mutu Pendidikan Sekolah Dasar. Jurnal FIP Universitas Negeri Malang, Vol 4, No 2

Eko Subiyanto .2018. Evaluasi Peran Kepemimpinan Kepala Sekolah Terhadap Kinerja Guru Sd Negeri Mangli Kecamatan Kaliangkrik Kabupaten Magelang Tahun 2018. Jurnal Mitra Pendidikan, Volume V, Nomor 3, Halaman: 264-273

Hoy, W.K \& Ferguson,J. 2018. A Theoretical Framework and Exploration of Organizational Effevtiveness in Schools. Journal of Educational Administration Quarterly, Volume 21 halaman 117-134

Nurasiah, Murniati AR, Cut Zahri Harun. 2015. Strategi Kepala Sekolah Dalam Peningkatan Mutu Di SD Negeri 1 Peukan Bada Aceh Besar, Banda Aceh. Universitas Syiah Kuala. Jurnal Magister Administrasi Pendidikan. Vol 6, No 4, hal 118-126.

Ruslan. 2020. Membangun Karakter Sekolah Bermutu Melalui Komunikasi Yang Efektif. JUPE: Jurnal Pendidikan Mandala. Vol. 5. No. 6, Halaman: 36-45

Trianto. 2010. Mendesain Model Pembelajaran Inovatif-Progresif: Konsep, Landasan, dan Implementasinya pada Kurikulum Tingkat Satuan Pendidikan (KTSP). Jakarta: Kencana 